\title{
Effect of Prenatal and Postnatal Prophylaxis with Macrolide for Ureaplasma on the Development of Bronchopulmonary Dysplasia in Preterm Infants
}

Euiseok Jung, M.D., Suyeong Kim, M.D., Young Hwa Jung, M.D., Juyoung Lee, M.D., Seung Han Shin, M.D., Chang Won Choi, M.D., Ph.D., Ee-Kyung Kim, M.D., Ph.D., Han-Suk Kim, M.D., Ph.D., Beyong Il Kim, M.D., Ph.D., and Jung-Hwan Choi, M.D., Ph.D.

Department of Pediatrics, Seoul National University College of Medicine, Seoul, Korea

\section{ABSTRACT}

Purpose: We aimed to evaluate the effects of two different macrolide prophylaxis protocols (prenatal and postnatal) for Ureaplasma on the development of bronchopulmonary dysplasia (BPD).

Methods: We retrospectively reviewed the medical charts of 121 preterm infants whose birth weights were $<1,250 \mathrm{~g}$ or gestational ages were $<30$ postmenstrual weeks. The demographic and clinical characteristics, including the presence of BPD, were compared between a prophylactic group, who received macrolide as prophylaxis prenatally and postnatally according to risk level, and a confirmed treatment group, who received macrolide prenatally and postnatally after detection of Ureaplasma infection.

Results: Seventy-four (61.2\%) of 121 preterm infants were included in the prenatal prophylaxis group. No significant differences in demographic characteristics were observed between the prenatal prophylaxis and prenatal confirmed treatment group. The detection rate of Ureaplasma and the frequency of postnatal therapeutic treatment with macrolide were lower in the prenatal prophylaxis group than in the prenatal confirmed treatment group ( $16.2 \%$ vs. $40.4 \%, P=0.003$; $8.1 \%$ vs. $48.9 \%, P<$ 0.001 , respectively). Although no significant differences in the incidence of moderate to severe BPD, the rate of severe BPD was lower in the prenatal prophylaxis group than in prenatal confirmed treatment group ( $18.9 \%$ vs. $40.4 \%, P=0.010)$. No significant differences in the incidences of BPD of any level of severity were observed between the postnatal prophylaxis and confirmed treatment groups.

Conclusion: Administration of prenatal prophylaxis with macrolide decreased the detection rate of Ureaplasma after birth and was associated with the decrease in the incidence of severe BPD in preterm infants.

Key Words: Bronchopulmonary dysplasia, Ureaplasma, Macrolides, Infants, Premature
Received: 28 February 2015

Revised: 5 May 2015

Accepted: 5 May 2015

Correspondence to:

Chang Won Choi, M.D., Ph.D. Department of Pediatrics, Seoul National University Bun-dang Hospital, 82 Gumi-ro 173 Beon-gil, Bundang-gu, Seongnam 463-707, Korea

Tel: +82-31-787-7286

Fax: +82-2-787-4054

E-mail: choicw@snu.ac.kr

Copyright(c)

By Korean Society of Neonatology.

All right reserved.

This is an Open-Access article distributed under the terms of the Creative Commons Attribution Non-Commercial License (http://creativecommons.org/licenses/ by-nc/3.0), which permits unrestricted non-commercial use, distribution, and reproduction in any medium, provided the original work is properly cited. 
서론

기관지폐형성이상(bronchopulmonary dysplasia, BPD)은 미 숙아의 폐에서 다양한 출생 전 및 출생 후 폐 손상의 결과로 발생 하는 다인성 질환이다 ${ }^{1,2)}$. 기관지폐형성이상의 출생 전 위험 인자 로서의 자궁 내 감염은 기관지폐형성이상의 원인적 인자일 뿐만 아니라, 출생 후 폐 손상을 가속화하는 인자로 알려져 있다3). 이러 한 자궁 내 감염을 일으키는 원인균들 중 유레아플라즈마(Ureaplasma)도 주요한 원인인 것으로 밝혀져 있단). 유레아플라즈마 는 가임기 여성의 40-80\%의 생식기에 존재하는 상재균이며, 미 숙아가 주산기에 가장 빈번하게 획득하게 되는 균이다 ${ }^{5,6)}$. 유레아 플라즈마는 미숙아의 폐에서 염증 반응에 대한 조절 장애를 유발 함으로써, 조기 섬유화를 통해 폐포화를 방해하여 기관지폐 이형 성을 유발하는 것으로 알려져 있다). 최근의 메타 분석들에서는 미숙아가 유레아플라즈마에 노출된 경우에 기관지폐형성이상의 위험도가 증가하는 것으로 보고하였으며8), 또한 미숙아에서 출생 후 마크로라이드(macrolide) 항생제를 이용하여 유레아플라즈마 를 제균 치료하는 것이 기관지폐형성이상의 발생 위험도를 감소시 킨다는 결과도 연구된 바 있다9). 그러나 마크로라이드 항생제를 산모에게 산전에 예방적으로 투약하는 것 또는 미숙아에게 출생 후 예방적으로 투약하는 것이 미숙아의 기관지폐형성이상의 발달 과 어떠한 관련성이 있는 지에 대한 연구는 현재까지 부족한 상황 이다. 이에 저자들은 본 연구에서 산전 마크로라이드 항생제의 예 방적 투약 정책이 다른 경우를 비교 분석하여 산전에 마크로라이 드 항생제를 예방적으로 투여하는 것과, 조기 양막 파수와 같은 유레아플라즈마 노출 위험군(1)에서 출생 후 미숙아에게 마크로라 이드 항생제를 예방적 투여한 경우가 각각 미숙아의 기관지폐형성 이상에 미치는 영향에 대해 연구하고자 하였다.

\section{대상 및 방법}

\section{1. 대상}

2012년과 2014년에 서울대학교병원과 분당서울대학교병원 신 생아 집중치료실에 입원한 원내 출생아로서 출생 체중 $1,250 \mathrm{~g}$ 미 만 또는 재태 나이 30주 미만 미숙아를 대상으로 하였다. 선천성 기형, 염색체 질환이 있는 경우 및 월경 후 나이 36주 이전 사망하 여 기관지폐형성이상의 중증도를 확인할 수 없었던 경우는 연구 대상에서 제외하였다. 당 기관의 임상연구윤리위원회의 승인 하 에 후향적 챠트 분석 연구를 진행하였고 동의서는 면제되었다(B1410/271-110)

\section{2. 방법}

연구 대상의 의무기록을 후향적으로 고찰하여 병력을 조사하였 다. 미숙아의 임상적 특성으로 재태 나이, 출생 체중, 성별, 부당경 량아, 출생 후 유레아플라즈마 검출, 신생아호흡곤란증후군, 동맥 관 개존증, 괴사성 장염, 기관지폐형성이상의 중증도, 출생 후 부 신피질호르몬 사용 및 마크로라이드 투약 여부 등을 확인하였다. 산모의 조기 양막 파수, 전자간증, 산전 부신피질호르몬 사용, 산 전 마크로라이드 투약 여부 등의 산과적 정보 또한 수집하였다.

본 연구는 2012년과 2014년에 서울대학교병원과 분당서울대학 교병원에서 치료 받은 미숙아들을 대상으로 시행되었다. 2013년 에 두 기관에서 치료 받은 미숙아들은 연구대상에서 제외가 되었 는데, 이는 2012년에는 두 기관 모두 출생 후 마크로라이드 예방 적 치료 방침을 채택하지 않았으나 분당서울대학교병원의 경우 2013년부터 증례에 따라(case by case) 출생 후 마크로라이드 예 방투약을 하기 시작하였고 2014년부터는 일관되게 출생 후 마크 로라이드 예방적 치료 방침을 적용하였기 때문에 치료 방침에 일 관성이 없었던 2013년의 자료는 채택하지 않았다. 서울대학교병원 에서는 2014년까지 출생 후 마크로라이드 예방투약 치료 방침을 적용하지 않았다. 또한 서울대학교병원에서는 일관되게 산전 마크 로라이드 예방투약 치료 방침을 적용하고 있는 반면 분당서울대학 교병원에서는 산전 마크로라이드 확인투약을 하고 있기 때문에 두 기관의 자료를 모아 서로 대조군으로 삼아 분석하게 되었다.

$<$ Treatment with macrolide to mother $>$

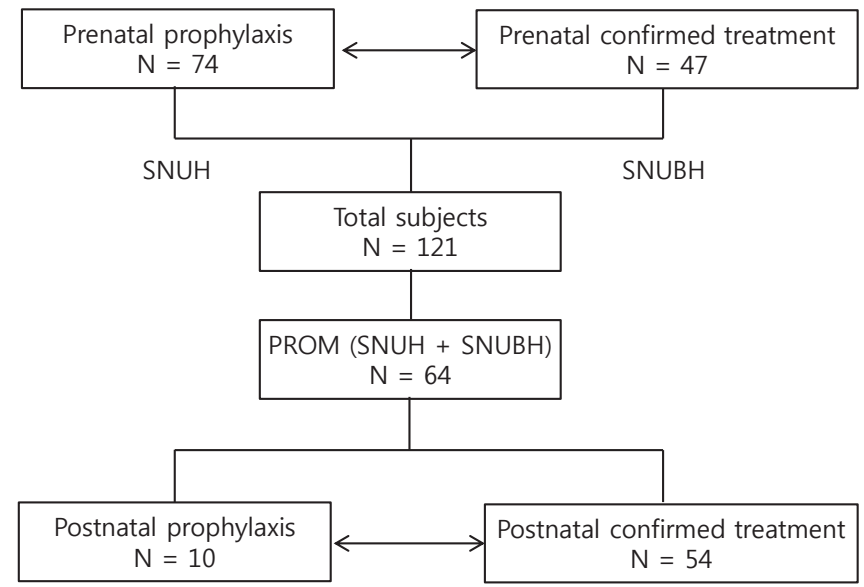

$<$ Treatment with macrolide to infant $>$

Figure 1. Comparison of the demographic and clinical characteristics between the prophylaxis and confirmed treatment groups of neonates who received who received macrolide, prenatally and postnatally. Abbreviations: SNUH, Seoul National University Hospital; SNUBH, Seoul National University Bundang Hospital; PROM, premature rupture of membranes. 
미숙아에서 유레아플라즈마를 검출하기 위해, 출생 직후 미숙 아에게 멸균 위관을 삽입하여 $1 \mathrm{~mL}$ 의 위액을 얻은 후, 배양 및 중 합 효소 연쇄반응(polymerase chain reaction, PCR) 검사를 시 행하였다. 배양 혹은 PCR 검사에서 양성 결과가 보고된 경우를 유 레아플라즈마 양성 검출로 정의하였다. 기관지폐형성이상은 2001 년 미국 국립보건원에서 제시한 기준(NICHD criteria) $)^{11}$ 을 사용 하였으며, 출생 후 최소 28 일 이상 산소 치료를 시행하였고, 교정 연령 36주 이후에도 흡입 산소 분압 0.3 미만의 산소가 필요한 경 우에는 중등도, 흡입 산소 분압 0.3 이상의 산소나 양압 환기 둘 다 혹은 어느 하나가 필요한 경우에는 중증의 기관지폐형성이상으로 구분하였다. 유의한 동맥관 개존증은 내과적 혹은 수술적 치료를 받은 경우로 한정하였으며, 괴사성 장염은 Bell의 기준에 따라 진 단하였다 ${ }^{12)}$.

산전 마크로라이드 투약 정책에 따른 임상적 특성을 비교하기 위해 다음과 같이 변수들을 정의하였다. 서울대병원과 분당서울대 병원 각각 두 기관의 산과 전문의들의 산전 마크로라이드 투약 정 책이 상이한 점에서 기인하여, 조기 양막 파수로 진단된 산모를 유 레아플라즈마 노출 위험군(10)으로 판단하여 양수 검사 결과와 무 관하게 산전 마크로라이드를 투약하는 정책을 지닌 서울대병원을 '산전 예방투약군', 양수 검사에서 유레아플라즈마가 확인된 경우 에 한하여 산전 마크로라이드를 투여하는 정책을 지닌 분당서울 대병원을 '산전 확인투약군'으로 구분하여 특성을 비교하였다 (Figure 1). 산모의 조기 양막 파수는 산과 전문의가 임상적으로 진단한 경우로 한정하였다. 산전 마크로라이드는 클래리스로마이 신(clarithromycin)이 사용되었으며 $50 \mathrm{mg}$ 용량을 1일 1회 용법 으로 출산 전 까지 총 2주 동안 산모에게 투여하였으며 '산전 예방 투약군'과 '산전 확인투약군'에서 동일한 용법을 사용하였다.

출생 후 마크로라이드 투약 정책에 따른 임상적 특성을 비교하 기 위해 연구 기간 중 두 기관의 모든 미숙아들을 합하여 유레아 플라즈마 노출 위험도가 높은 조기 양막 파수의 산모에게서 출생 한 미숙아들을 선택하여 분석하였다. 출생 후 미숙아에게 유레아 플라즈마 검출 확인 전 마크로라이드가 투여된 경우를 '출생 후 예방투약군, 유레아플라즈마 검출 확인 후 마크로라이드가 투여 된 경우를 '출생 후 확인투약군'으로 정의하였다(Figure 1). 에리 스로마이신(erythromicin) 1 일 $40 \mathrm{mg} / \mathrm{kg}$ 용량을 10일간, 클래리 스로마이신 1일 $20 \mathrm{mg} / \mathrm{kg}$ 용량을 2주간, 혹은 아지스로마이신 (azithromycin) 1일 $10 \mathrm{mg} / \mathrm{kg}$ 용량을 1주일 사용 후 1일 $5 \mathrm{mg} /$ $\mathrm{kg}$ 로 감량하여 최대 6주간 사용하는 용법 중 한 가지를 출생 후 미숙아에게 마크로라이드 치료 요법으로 사용하였다. 연구에 등 록된 모든 미숙아들은 동일한 진료 지침에 따라 관리되었다.

\section{3. 통계분석}

본 연구에서 통계분석은 SPSS Version 18.0 (SPSS Inc., Chica- go, IL, USA)을 사용하였다. 연속 변수는 $t$ 검정을 이용하여 평균 값(표준편차)으로 나타내었고, 비연속 변수는 카이 제곱 검정 및 피셔의 정확한 검정을 이용하여 빈도수(백분율)로 나타내었다.

\section{결과}

\section{1. 연구 대상의 임상적 특성}

연구 대상 121 명의 재태 나이는 $26^{+5}$ 주 $\left(2^{+6}\right)$, 출생 체중은 909.3 $\mathrm{g}$ (221.2) 이었고 남녀 비는 1:1.05 이었다. 산모의 조기 양막 파수 는 64 명(52.9\%), 전자간증은 12 명(9.9\%)에서 확인되었다. 출생 후 미숙아에서 검사한 유레아플라즈마는 31명(25.6\%)에서 양성으 로 보고되었다. 대상 환자들 중 중등도 기관지폐형성이상으로 진 단된 환자는 68 명(56.2\%), 중증 기관지폐형성이상으로 진단 된 환 자는 33명(27.3\%)이었다.

\section{2. 산전 마크로라이드 투약 정책에서 예방투약군과 확인투약 군 간의 임상적 특성 비교}

총 121 명의 미숙아가 산전 마크로라이드 투약 정책 분석 대상

Table 1. Demographic Characteristics and Clinical Outcomes of Preterm Infants Who Received the Prenatal Prophylaxis Protocol of Macrolide

\begin{tabular}{lccr}
\hline & $\begin{array}{c}\text { Prophylaxis } \\
(\mathrm{n}=74)\end{array}$ & $\begin{array}{c}\text { Confirmed } \\
\text { treatment } \\
(\mathrm{n}=47)\end{array}$ & $P$-value \\
\hline Gestational age (wks) & $26^{+4}\left(3^{+3}\right)$ & $27^{+1}\left(\mathrm{l}^{+2}\right)$ & 0.283 \\
Birth weight (g) & $896.4(225.2)$ & $929.7(215.4)$ & 0.421 \\
Female & $38(51.4)$ & $24(51.1)$ & 0.975 \\
Small for gestational age & $8(10.8)$ & $5(10.6)$ & 0.976 \\
PROM & $41(55.4)$ & $23(48.9)$ & 0.487 \\
Preeclampsia & $7(9.5)$ & $5(10.6)$ & 0.532 \\
Antenatal corticosteroid use & $64(86.5)$ & $43(91.5)$ & 0.562 \\
Antenatal macrolides use & $49(66.2)$ & $5(10.6)$ & $<0.001$ \\
RDS & $61(82.4)$ & $41(87.2)$ & 0.479 \\
PDA treatment & $46(62.2)$ & $22(46.8)$ & 0.132 \\
NEC stage $\geq 2$ & $10(13.5)$ & $2(4.3)$ & 0.125 \\
Detection of Ureaplasma & $12(16.2)$ & $19(40.4)$ & 0.003 \\
Postnatal macrolide use & $6(8.1)$ & $23(48.9)$ & $<0.001$ \\
Postnatal corticosteroid use & $9(12.2)$ & $11(23.4)$ & 0.105 \\
Moderate to severe BPD & $39(52.7)$ & $29(61.7)$ & 0.331 \\
Severe BPD & $14(18.9)$ & $19(40.4)$ & 0.010 \\
\hline
\end{tabular}

Data are presented as numbers (\%) and mean (SD).

Abbreviations: PROM, premature rupture of membranes; RDS, respiratory distress syndrome; PDA, patent ductus arteriosus; NEC, necrotizing enterocolitis; $\mathrm{BPD}$, bronchopulmonary dysplasia; SD, standard deviation. 
Table 2. Demographic Characteristics and Clinical Outcomes of Preterm Infants Who Received the Postnatal Prophylaxis Protocol of Macrolide after Premature Rupture of Membranes

\begin{tabular}{lccc}
\hline & $\begin{array}{c}\text { Prophylaxis } \\
(\mathrm{n}=10)\end{array}$ & $\begin{array}{c}\text { Confirmed } \\
\text { treatment } \\
(\mathrm{n}=54)\end{array}$ & $\begin{array}{c}P \text { - } \\
\text { value }\end{array}$ \\
\hline Gestational age (wks) & $26^{+5}\left(\mathrm{l}^{+3}\right)$ & $26^{+5}\left(\mathrm{l}^{+1}\right)$ & 0.775 \\
Birth weight $(\mathrm{g})$ & $944.5 .(176.4)$ & $923.6(216.2)$ & 0.934 \\
Female & $5(50)$ & $27(50)$ & 0.835 \\
Small for gestational age & $0(0)$ & $2(3.7)$ & 0.710 \\
Antenatal corticosteroid use & $10(100)$ & $47(87)$ & 0.355 \\
RDS & $10(100)$ & $43(79.6)$ & 0.188 \\
PDA treatment & $4(40)$ & $33(61.1)$ & 0.300 \\
NEC stage $\geq 2$ & $0(0)$ & $7(13)$ & 0.584 \\
Detection of Ureaplasma & $4(40)$ & $17(31.5)$ & 0.717 \\
Postnatal corticosteroid use & $4(40)$ & $9(16.7)$ & 0.192 \\
Moderate to severe BPD & $6(60)$ & $32(59.3)$ & 0.625 \\
Severe BPD & $2(20)$ & $17(31.5)$ & 0.710
\end{tabular}

Data are presented as numbers (\%) and mean (SD).

Abbreviations: RDS, respiratory distress syndrome; PDA, patent ductus arteriosus; NEC, necrotizing enterocolitis; BPD, bronchopulmonary dysplasia; SD, standard deviation.

에 해당하였고 이 중에 74명(61.2\%)이 산전 예방투약군에, 나머지 47명(38.8\%)이 산전 확인투약군에 해당하였다(Table 1). 예방투 약군과 확인투약군 간에 미숙아들의 재태 나이, 출생 체중, 성비, 부당경량아 비율의 유의한 차이는 보이지 않았다. 또한 두 군 간에 산모의 조기 양막 파수, 전자간증의 비율 및 산전 부신피질호르몬 의 투여 빈도에도 차이가 없었다. 하지만 예방투약군에서 산전 마 크로라이드 투여 빈도가 확인투약군에 비하여 유의하게 높았다 (66.2\% vs. 10.6\%, $P<0.001)$. 출생 후 유레아플라즈마 검출률은 예방투약군에서 유의하게 낮았으며(16.2\% vs. $40.4 \%, P=0.003)$, 확인투약군에서 출생 후 미숙아에게 유레아플라즈마에 대한 마 크로라이드 투약 치료가 더 자주 행해졌다 $8.1 \%$ vs. $48.9 \%, P<$ 0.001). 두 군 간에 신생아호흡곤란증후군, 유의한 동맥관 개존증, 괴사성 장염의 발병률 및 출생 후 부신피질호르몬의 투여 빈도의 차이는 없었다. 중등도 이상의 기관지폐형성이상의 발병률은 두 군 사이의 차이는 없었으나, 증증의 기관지폐형성이상의 발병률은 예방투약군이 확인투약군에 비해 낮게 확인 되었다 $(18.9 \%$ vs. $40.4 \%, P=0.010$ )

\section{3. 출생 후 마크로라이드 투약 정책에서 예방투약군과 확인투 약군 간의 임상적 특성 비교}

총 64 명의 미숙아가 출생 후 마크로라이드 투약 정책 분석 대상 에 해당하였고 이 중에 10명(15.6\%)이 출생 후 예방투약군에, 나 머지 54명(84.4\%)이 출생 후 확인투약군에 해당하였다(Table 2).
예방투약군과 확인투약군 간에 미숙아들의 재태 나이, 출생 체중, 성비, 부당경량아 비율 및 출생 전 부신피질호르몬 투약 여부 등의 유의한 차이는 보이지 않았다. 두 군 간에 신생아호흡곤란증후군, 유의한 동맥관 개존증, 괴사성 장염의 발병률 및 출생 후 부신피질 호르몬의 투여 빈도의 차이는 없었다. 또한 중등도 이상의 기관지 폐형성이상의 발병률 및 중증의 기관지폐형성이상의 발병률도 두 군간에 차이를 보이지 않았다.

\section{고찰}

유레아플라즈마는 스스로 생존할 수 있는 가장 작은 세균으로 서 세포벽이 없다는 특징을 지니고 있어 페니실린 혹은 세팔로스 포린 항생제에 저항성을 지닌다 ${ }^{6,13)}$. 따라서 의학적으로 유레아플 라즈마를 치료하기 위해서는 테트라사이클린, 퀴놀론, 클로람페니 콜 및 마크로라이드 항생제가 필요하다 ${ }^{(4)}$. 하지만 마크로라이드를 제외한 기타 항생제들은 신생아 시기에 투약할 경우 장기적인 부 작용이 보고되어 추천되지 않으므로 태아 및 신생아에게는 마크 로라이드 항생제를 유레아플라즈마 치료에 사용하게 되었다 ${ }^{3)}$.

본 연구의 결과로 볼 때 산전에 마크로라이드에 대한 예방적 치 료를 한 군에서 출생 직후 미숙아에게 유레아플라즈마 검출률이 낮았고 따라서 출생 후 마크로라이드 치료의 빈도 또한 줄어들었 던 것으로 추정된다. 산전 확인투약군에서는 출생 후 마크로라이 드 항생제가 보다 빈번하게 투여되었으나 미숙아의 중증의 기관지 폐형성이상을 감소시키지는 못하였다. 영장류 실험에서 자궁 내 유레아플라즈마 감염을 마크로라이드로 치료한 경우가 그렇지 않 은 경우에 비해 폐 손상이 줄어드는 것을 확인한 바 있으멷), 인 간 미숙아 대상 연구에서는 출생 직후 위액의 유레아플라즈마의 양성 검출이 미숙아에게서 중등도의 기관지폐형성이상의 발병률 차이를 야기하지는 않았으나, 중증의 기관지폐형성이상의 발병률 은 높이는 것으로 보고된 바가 있다 ${ }^{16)}$. 총 4,286명의 산모를 대상 으로 한 대규모 ORACLE 연구에서 조기 양막 파수가 된 산모에게 에리스로마이신을 투여하는 것은 출생 후 신생아의 기관지폐형성 이상 및 사망을 감소시켰다 ${ }^{17}$. 따라서 본 연구에서 자궁 내 유레아 플라즈마 감염의 위험성이 높은 산모에게 예방적으로 마크로라이 드 항생제를 투약하였던 것과 출생 후 미숙아의 중증의 기관지폐 형성이상의 발병률 감소와의 연관성을 추정해볼 수 있다.

유레아플라즈마에 노출된 기간이 길어질수록 폐 손상은 악화 된다 ${ }^{18)}$. 최근의 연구결과에서 출생 후 조기에 아지스로마이신을 통하여 예방적으로 치료하여 기관지폐형성이상의 발병률을 줄였 다는 보고가 있다9). 하지만 본 연구에서는 조기 양막 파수의 유레 아플라즈마 노출 위험군에서(10) 출생 후에 예방적으로 마크로라이 드를 투여하는 정책과 유레아플라즈마 확인 후 투여하는 정책과 
의 비교에서 미숙아의 기관지폐형성이상의 발병률의 차이를 확인 하지 못하였다. 이 결과는 아지스로마이신 단독이 아닌 여러 종류 의 마크로라이드 항생제들을 사용하였기 때문일 가능성도 배제 할 수 없다. 하지만 출생 후 치료보다 시기적으로 더 이른 산전 예 방적 마크로라이드 치료를 통해 중증의 기관지폐형성이상의 발병 률이 감소된 결과를 통해 유레아플라즈마의 노출 기간과 장기적 인 폐 손상의 연관성을 상기해볼 수 있다 ${ }^{18)}$.

본 연구에서는 미숙아 출생 직후에 위액을 획득하여 유레아플 라즈마를 검사하였다. 출생 직후의 위액이 양수 및 출생 전 폐액과 밀접한 접촉이 있으므로, 위액 내의 유레아플라즈마 양성 검출이 태아의 폐에 유레아플라즈마의 노출을 반영한다고 가정한다 ${ }^{16)}$. 이 러한 방법은 비침습적 환기 치료를 받는 신생아에게 기관 흡입 검 체를 얻는 것이 현실적이지 않다는 점에서 대안적인 장점이 있다. 또한 본 연구에서 배양 및 PCR 검사를 조합한 방법은 유레아플라 즈마 검출의 신뢰도를 높이는 것으로 알려져 있다 ${ }^{19)}$. 유레아플라 즈마 양성이었던 31명은 모두 PCR 검사에서 양성이었으며, 그 중 12 명에서 배양 검사 양성이었다. 이러한 결과에서 유레아플라즈 마를 검출하는 데에 PCR이 좀더 예민한 검사임을 유추해볼 수 있 달) 상기 검출법으로 연구 대상의 $25.6 \%$ 에서 유레아플라즈마 양성이 보고되었으며 극소 저체중 출생아 $(<1,500 \mathrm{~g})$ 에서 $20-45 \%$ 로 보고되었던 이전의 연구와 비슷한 수치이다6).

마크로라이드 항생제는 부정맥, 비후성 유문 협착증 등의 심각 한 부작용이 보고되어 있다 ${ }^{21,22)}$. 하지만 연구 대상 집단에서 마크 로라이드를 투약한 이후 상기 부작용은 보고되지 않았다. 마크로 라이드 항생제는 소아 및 성인에서 QT간격 연장의 부정맥을 야기 한다고 알려져 있으나 ${ }^{21)}$, 신생아 및 미숙아에서는 그 부작용이 뚜 렷하지 않은 것으로 보고되어 있으며 ${ }^{23)}$, 과용량으로 투약하여 부 정맥이 발생한 1 개의 증례만이 현재까지 신생아에 보고되어 있다 24) 하지만 미숙아에서 출생 초기 장기간의 예방적 항생제 투여는 예상치 못한 다양한 부작용을 발생시킬 수 있으므로 투약에 주의 가 필요하다 ${ }^{25)}$.

본 연구는 후향적 연구로 해석의 제한이 있으며, 산전 마크로라 이드 투약 정책과 출생 후 마크로라이드 투약 정책의 효과를 직접 비교하지는 못하였고, 연구 대상의 신경학적 예후를 조사하지 않 고 ${ }^{26)}$, 호흡기 예후만을 평가하였다는 데에 한계가 있다. 또한 기관 지폐형성이상의 다양한 위험인자들 중 기계환기기 사용 기간, 산 소 노출 기간, 패혈증 등을 모두 분석하지 못하였기 때문에 그 결 과의 해석에 제한이 있을 수 있다 ${ }^{27}$. 사용한 마크로라이드 항생제 의 종류도 다양하였기에 결과 도출에 영향을 주었을 가능성도 배 제할 수 없다. 하지만 미숙아를 대상으로 하여, 출생 전 및 출생 후 예방적 마크로라이드 치료가 기관지폐형성이상의 발달에 미치는 영향에 대해 유레아플라즈마 검출 결과를 포함한 첫 번째 연구라 는데 의미가 있다.
현재 미국산부인과협회의 진료 지침에는 만삭전 조기 양막 파 수의 경우에 광범위 항생제를 투약하며 에리스로마이신의 추가도 고려할 것을 권고하고 있다 ${ }^{28)}$. 향후 미숙아의 기관지폐형성이상의 발달에 마크로라이드 치료가 미치는 영향에 대한 대규모의 전향 적 무작위 비교 연구가 필요할 것으로 생각된다.

\section{REFERENCES}

1) Jobe $\mathrm{AH}$. Antenatal associations with lung maturation and infection. J Perinatol 2005;25 Suppl 2:S31-5.

2) Choi CW, Kim BI. Epidemiology, clinical characteristics, and pathophysiology of bronchopulmonary dysplasia. Neonatal Med 2013;20:283-91.

3) Speer CP. Inflammation and bronchopulmonary dysplasia: a continuing story. Semin Fetal Neonatal Med 2006;11:354-62.

4) Cassell GH, Waites KB, Watson HL, Crouse DT, Harasawa R. Ureaplasma urealyticum intrauterine infection: role in prematurity and disease in newborns. Clin Microbiol Rev 1993;6:69-87.

5) Waites KB, Katz B, Schelonka RL. Mycoplasmas and ureaplasmas as neonatal pathogens. Clin Microbiol Rev 2005;18:75789.

6) Viscardi RM. Ureaplasma species: role in neonatal morbidities and outcomes. Arch Dis Child Fetal Neonatal Ed 2014;99: F87-92.

7) Viscardi RM, Hasday JD. Role of Ureaplasma species in neonatal chronic lung disease: epidemiologic and experimental evidence. Pediatr Res 2009;65:84R-90R.

8) Lowe J, Watkins WJ, Edwards MO, Spiller OB, Jacqz-Aigrain E, Kotecha SJ, et al. Association between pulmonary ureaplasma colonization and bronchopulmonary dysplasia in preterm infants: updated systematic review and meta-analysis. Pediatr Infect Dis J 2014;33:697-702.

9) Nair V, Loganathan P, Soraisham AS. Azithromycin and other macrolides for prevention of bronchopulmonary dysplasia: a systematic review and meta-analysis. Neonatology 2014;106: 337-47.

10) Calleri LF, Taccani C, Porcelli A. Ureaplasma urealyticum vaginosis and premature rupture of membranes. What is its role? Minerva Ginecol 2000;52:49-58

11) Jobe AH, Bancalari E. Bronchopulmonary dysplasia. Am J Respir Crit Care Med 2001;163:1723-9.

12) Bell MJ, TernbergJL, Feigin RD, KeatingJP, Marshall R, Barton L, et al. Neonatal necrotizing enterocolitis. Therapeutic decisions based upon clinical staging. Ann Surg 1978;187:1-7.

13) Bührer C, Hoehn T, Hentschel J. Role of erythromycin for treatment of incipient chronic lung disease in preterm infants 
colonised with Ureaplasma urealyticum. Drugs 2001;61:18939.

14) Matlow A, Th'ng C, Kovach D, Quinn P, Dunn M, Wang E. Susceptibilities of neonatal respiratory isolates of Ureaplasma urealyticum to antimicrobial agents. Antimicrob Agents Chemother 1998;42:1290-2.

15) Grigsby PL, Novy MJ, Sadowsky DW, Morgan TK, Long M, Acosta E, et al. Maternal azithromycin therapy for Ureaplasma intraamniotic infection delays preterm delivery and reduces fetal lung injury in a primate model. Am J Obstet Gynecol 2012;207:475.e1-14.

16) Oue S, Hiroi M, Ogawa S, Hira S, Hasegawa M, Yamaoka S, et al. Association of gastric fluid microbes at birth with severe bronchopulmonary dysplasia. Arch Dis Child Fetal Neonatal Ed 2009;94:F17-22.

17) Kenyon SL, Taylor DJ, Tarnow-Mordi W. Broad-spectrum antibiotics for preterm, prelabour rupture of fetal membranes: the ORACLE I randomized trial. ORACLE Collaborative Group. Lancet 2001;357:979-88.

18) Novy MJ, Duffy L, Axthelm MK, Sadowsky DW, Witkin SS, Gravett MG, et al. Ureaplasma parvum or Mycoplasma hominis as sole pathogens cause chorioamnionitis, preterm delivery, and fetal pneumonia in rhesus macaques. Reprod Sci 2009;16:56-70.

19) Gerber S, Vial Y, Hohlfeld P, Witkin SS. Detection of Ureaplasma urealyticum in second-trimester amniotic fluid by polymerase chain reaction correlates with subsequent preterm labor and delivery. J Infect Dis 2003;187:518-21.

20) Luki N, Lebel P, Boucher M, Doray B, Turgeon J, Brousseau R. Comparison of polymerase chain reaction assay with culture for detection of genital mycoplasmas in perinatal infections. Eur J Clin Microbiol Infect Dis 1998;17:255-63.

21. Ray WA, Murray KT, Hall K, Arbogast PG, Stein CM. Azithromycin and the risk of cardiovascular death. N Engl J Med 2012;366:1881-90.

22) Mahon BE, Rosenman MB, Kleiman MB. Maternal and infant use of erythromycin and other macrolide antibiotics as risk factors for infantile hypertrophic pyloric stenosis. J Pediatr 2001;139:380-4.

23) Viscardi RM, Othman AA, Hassan HE, Eddington ND, Abebe E, Terrin ML, et al. Azithromycin to prevent bronchopulmonary dysplasia in ureaplasma-infected preterm infants: pharmacokinetics, safety, microbial response, and clinical outcomes with a 20-milligram-per-kilogram singleintravenous dose. Antimicrob Agents Chemother 2013;57:2127-33.

24) Tilelli JA, Smith KM, Pettignano R. Life-threatening bradyarrhythmia after massive azithromycin overdose. Pharmacotherapy 2006;26:147-50.

25) Kuppala VS, Meinzen-Derr J, Morrow AL, Schibler KR. Prolonged initial empirical antibiotic treatment is associated with adverse outcomes in premature infants. J Pediatr 2011; 159:720-5.

26) Viscardi RM, Hashmi N, Gross GW, Sun CC, Rodriguez A, Fairchild KD. Incidence of invasive ureaplasma in VLBW infants: relationship to severe intraventricular hemorrhage. J Perinatol 2008;28:759-65.

27) Park EA. Factors of bronchopulmonary dysplasia and prediction in Korea. Neonatal Med 2013;20:292-9.

28) Committee on Practice Bulletins-Obstetrics. Practice bulletins No. 139: premature rupture of membranes. Obstet Gynecol 2013;122:918-30. 